\title{
Plutonium Immobilization Bagless Transfer Can Size Evaluation
}

by

E. Kriikku

Westinghouse Savannah River Company

Savannah River Site

Aiken, South Carolina 29808

M. Stokes

L. Rogers

C. Ward

This paper was prepared in connection with work done under the above contract number with the U. S. Department of Energy. By acceptance of this paper, the publisher and/or recipient acknowledges the U. S. Government's right to retain a nonexclusive, royalty-free license in and to any copyright covering this paper, along with the right to reproduce and to authorize others to reproduce all or part of the copyrighted paper. 


\section{DISCLAIMER}

This report was prepared as an account of work sponsored by an agency of the United States Government. Neither the United States Government nor any agency thereof, nor any of their employees, makes any warranty, express or implied, or assumes any legal liability or responsibility for the accuracy, completeness, or usefulness of any information, apparatus, product, or process disclosed, or represents that its use would not infringe privately owned rights. Reference herein to any specific commercial product, process, or service by trade name, trademark, manufacturer, or otherwise does not necessarily constitute or imply its endorsement, recommendation, or favoring by the United States Government or any agency thereof. The views and opinions of authors expressed herein do not necessarily state or reflect those of the United States Government or any agency thereof.

This report has been reproduced directly from the best available copy.

Available to DOE and DOE contractors from the Office of Scientific and Technical Information, P. O. Box 62, Oak Ridge, TN 37831; prices available from (423) 576-8401.

Available to the public from the National Technical Information Service, U. S. Department of Commerce, 5285 Port Royal Road, Springfield, VA 22161. 


\section{DISCLAIMER}

Portions of this document may be illegible electronic image products. Images are produced from the best available original document. 


\section{Plutonium Immobilization Puck}

Can Size Evaluation (U)

February 13, 1998

Westinghouse Savannah River Company Savannah River Site

Aiken, SC 29808 


\title{
Plutonium Immobilization Puck Can Size Evaluation (U)
}

The following Plutonium Immobilization Can Loading Team members contributed to this report.

\author{
Bill Randall \\ NMS\&S \\ Jim Steed \\ NMS\&S \\ Robert Jones \\ NMS\&S \\ Clyde Ward \\ SRTC/EES \\ Mitchell Stokes \\ SRTC/EES \\ Lane Rogers \\ SRTC/EES
}

Lee Hamilton

SRTC/EES

Greg Dyches

SRTC/EES

Eric Kriikku

SRTC/EES 


\section{TABLE OF CONTENTS}

SUMMARY

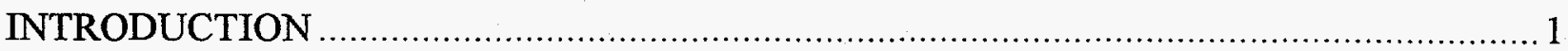

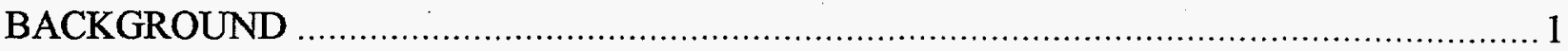

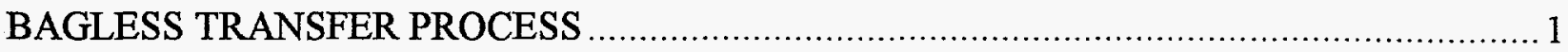

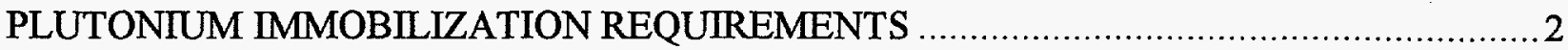

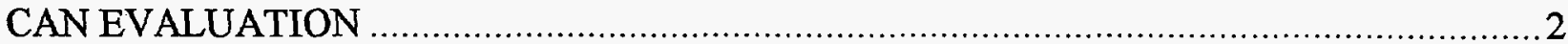

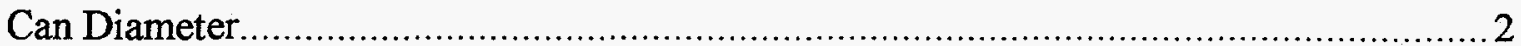

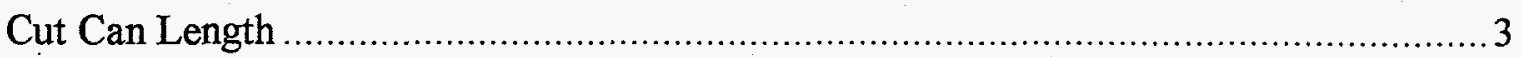

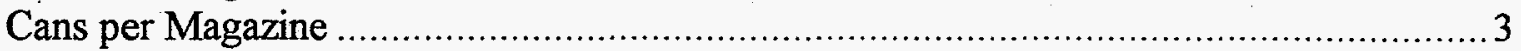

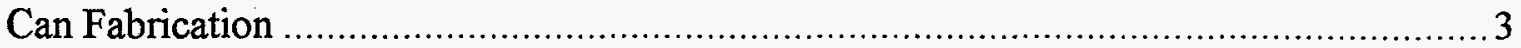

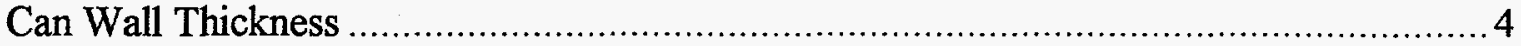

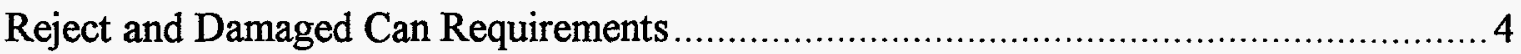

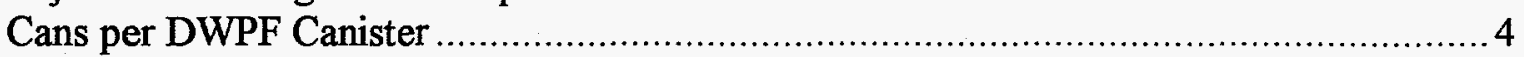

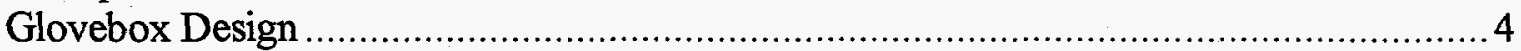

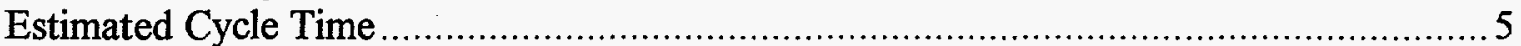

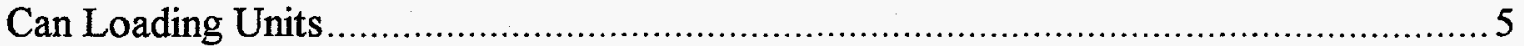

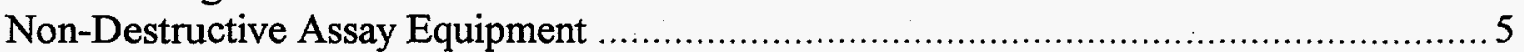

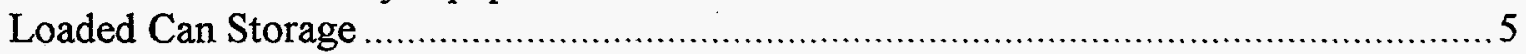

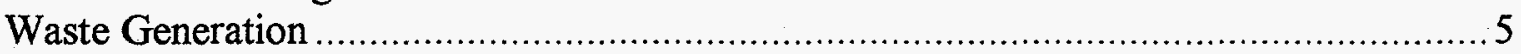

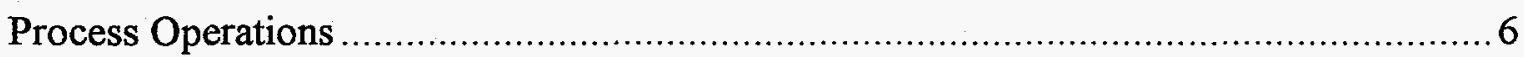

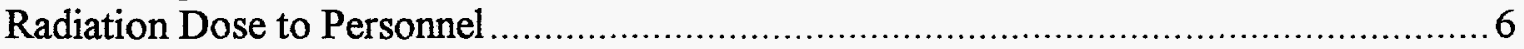

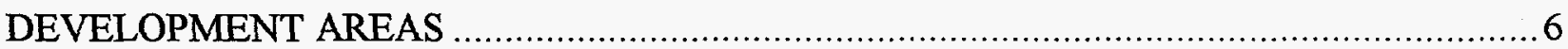

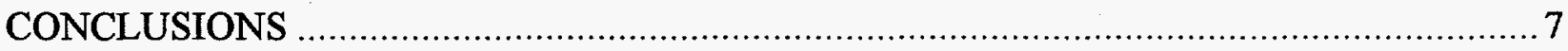

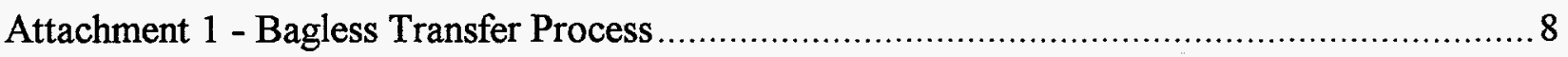

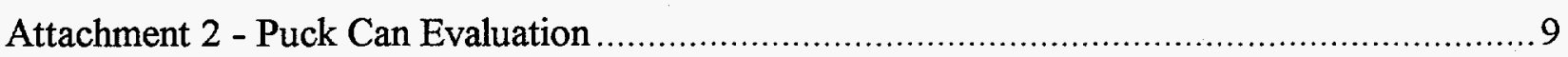

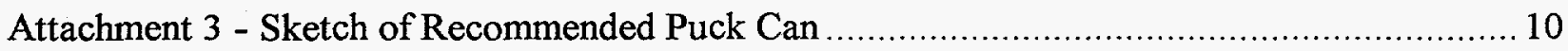




\section{SUMMARY}

The Plutonium Immobilization Facility will encapsulate plutonium in ceramic pucks and seal the pucks inside welded cans. Remote equipment will place these cans in magazines and put seven magazines in a Defense Waste Processing Facility (DWPF) canister. The DWPF will fill the canister with glass for permanent storage. This report evaluates various can parameters such as; can diameter, can wall thickness, and can length. This report recommends a 3 inch outer can diameter based on the DWPF canister neck size limitations. This report recommends a 0.06 inch nominal can wall thickness based on the Savannah River Site (SRS) FB-Line Bagless Transfer can experience. However, can wall thickness requires more analysis to verify hot DWPF glass will not compromise can integrity. This report considers three different nominal can lengths; 10 inch, 20 inch and 80 inch. The disadvantages for the 10 inch can include; a high number of can loading units required to meet production rates and the associated high number of support process operations. The disadvantages for the 80 inch can include; high development costs, technical risk, and challenging glovebox operations due to large can size and weight. The advantages for the 20 inch can include; the design is based on the SRS FB-Line Bagless Transfer system, the can size and weight are compatible with glovebox operations, technical risk is low, and cycle time required to meet production rates is acceptable. This report recommends a 20 inch tall can for the Plutonium Immobilization Facility Can Loading system.

\section{INTRODUCTION}

This report identifies and documents the most appropriate puck can size to support Plutonium Immobilization Can Loading operations. This report considers can diameter, can wall thickness, and can length. Report recommendations use all available information at the time of writing.

\section{BACKGROUND}

The Plutonium Immobilization Facility design will minimize operator exposure, contain contamination, and prevent the spread of contamination. To accomplish these goals, a system will package contaminated materials in clean containers and not release contamination. Traditional methods of removing plutonium from process gloveboxes in preparation for packaging involves the use of bagout procedures utilizing plastic bags. This method creates additional waste material that is potentially contaminated from the glovebox atmosphere. Engineers at the Savannah River Site have developed a system for removing plutonium from a glovebox directly into an all metal, welded, leaktight container, free of external contamination. The process, known as bagless transfer, utilizes a Tungsten-Inert-Gas (TIG) welding process to seal plutonium in a can. The process then separates the transfer can from the glovebox environment while maintaining glovebox and can integrity. A semi-automated bagless transfer unit is in operation at the Savannah River Site FB-Line Plutonium Facility.

\section{BAGLESS TRANSFER PROCESS}

Steps 1-5 of Attachment 1 show the basic bagless transfer process. The first step in the process is to insert a new can into the bottom of the glovebox, (step 1). The new can displaces the remaining portion of the previous can from the sphincter seal. Next, the material to be transferred is placed inside the can, (step 2). A hollow plug is then inserted into the can and the can is fused to the hollow plug via a TIG welding process through the container wall, (step 3). 
The can is then cut (using a roller wheel equipped pipe cutter) in the middle of the welded area, separating the can from the glovebox while maintaining the integrity of both, (steps 4 and 5). After cutting, the can upper portion (stub) remains in the sphincter seal to maintain glovebox integrity, and the bottom portion forms a leaktight, all-metal, welded container.

\section{PLUTONIUM IMMOBILIZATION REQUIREMENTS}

The Plutonium Immobilization facility must produce approximately 560 pucks per day to meet production requirements. The can loading system must be able to automatically load 24 pucks per hour at the minimum into puck cans. The puck cans are loaded into magazines, and magazines are loaded into DWPF canisters. The DWPF canisters are filled with approximately 91 inches of glass and the puck cans, magazines, and racks must be contained in the glass.

Normal can loading system operations will be performed automatically and/or remotely. These operations include:

- Unloading pucks from trays

- Weighing and inspecting pucks

- Loading of ceramic pucks into the can

- Performing the bagless transfer operations

- Unloading can from bagless transfer unit

- Transfer to and through a Non Destructive Examination (NDE) station for leak \& contamination detection (smear test)

- Transfer to and through the Non Destructive Assay (NDA) station (Not funded in FY98)

- Transfer to canister loading operations

\section{CAN EVALUATION}

The following sections evaluate various can parameters and Attachment 2 summarized these parameters.

\section{Can Diameter}

The following factors limit puck can diameter. First, the DWPF canister neck has an inner diameter of 4.5 inches (radius of 2.25 inches). Second, there must be a protective sleeve on the canister to prevent damage to the canister neck. This sleeve is estimated to be 0.125 inches thick. Third, there must be some clearance for the magazine to fit through the protective sleeve. This clearance is estimated at 0.25 inches on either side. Fourth, the magazine is estimated to be 0.25 inches thick. Fifth, there needs to be some clearance for the can to fit in the magazine. This clearance is estimated at 0.125 inches on either side. The remaining 3.0 inches ( 1.5 inch radius) is the maximum can outer diameter, see Table 1 for details. 


\section{Table 1 - Can Diameter Limitations}

$\begin{array}{lr}\text { Canister Neck Radius } & 2.250 \text { inches } \\ \text { Protective Sleeve Thickness } & -0.125 \text { inches } \\ \text { Sleeve to Magazine Clearance } & -0.250 \text { inches } \\ \text { Magazine Thickness } & -0.250 \text { inches } \\ \text { Magazine to Can Clearance } & -0.125 \text { inches } \\ \text { Max Can Outer Radius } & 1.500 \text { inches }\end{array}$

\section{Cut Can Length}

The cut can length is the can length after the can is cut from the can loading unit. This report evaluates nominal can lengths of 10 inches, 20 inches and 80 inches. The following explains the reasons for choosing these lengths.

- 10 inch can: The SRS FB-Line Bagless Transfer system produces a 4.5 inch tall can. With minor modifications, this system can accommodate a 10 inch tall can. This can length requires the least development and therefore is included in this report.

- 20 inch can: The FB-Line Bagless Transfer system can be modified to accommodate a 20 inch tall can. This is the longest length suitable for the current design (i.e. vertical orientation), and therefore is included in this report.

- 80 inch can: The 80 inch can requires a complete new can loading system design. A single 80 inch can could replace a magazine containing multiple cans. Due to this advantage, this report considers 80 inch tall cans.

Note that an empty can must be approximately 10 inches longer than a cut can. This 10 inch section is left in the can loading system after the can is cut off. It maintains the containment in the sphincter seals until the next can is inserted. This 10 inch section is pushed into the glovebox by the next can, and is disposed of as waste.

\section{Cans per Magazine}

One magazine requires eight 10 inch cans, four 20 inch cans, or one 80 inch can. Each DWPF canister requires 7 magazines. It is advantageous to use the least number of cans per magazine from a material handling standpoint. The 80 inch tall can represents the least number of cans required per magazine and is the tallest can that would fit in the DWPF canister. The current magazine concept includes a solid top for lifting, a welded wire frame, and a solid bottom.

\section{Can Fabrication}

Much time was spent in the SRS Bagless Transfer Program working out design details so a vendor could produce a can and plug with realistic and acceptable tolerances necessary for the fusion weld process. Extending the can to 20 inches requires minimal can redesign, some can development, and minor technical risk to meet the required tolerances. An 80 inch can requires significant redesign, significant development, and major technical risk to meet the required tolerances. If the can thickness changes, as may be required for an 80 inch can, this will upset the can/plug interface at the weld region and will require a thorough weld qualification program to verify can integrity to withstand the stresses of being lifted into the magazine after filling. Can fabrication requires more analysis to verify hot DWPF glass will not compromise can integrity. 


\section{Can Wall Thickness}

The SRS Bagless Transfer system uses a 0.06 inch (nominal) thick can wall. This thickness is considered reasonable for both the 10 inch can and the 20 inch can for the Plutonium Immobilization application. A thicker wall may be required for an 80 inch can as previously mentioned. The 1200 degrees Celsius DWPF glass will reduce the can wall strength and expand internal gasses causing internal pressure to rise. Can wall thickness requires more analysis to verify hot DWPF glass will not compromise can integrity.

\section{Reject and Damaged Can Requirements}

In the case of a reject can, i.e., a welder failure, the entire can must be pushed into can loading glovebox. The SRS Bagless Transfer unit can accommodate a rejected 10 inch can or 20 inch can. If an 80 inch can is used, it will be impractical to process in the vertical orientation, thus requiring a glovebox with an 80 inch long access way for can entry on one side, as well as an 80 inch long wing on the other side to allow the ejection of a failed can. It is possible to use a cutoff saw inside the box in lieu of the ejection wing, but it is felt that the glovebox would have to be made wider to accommodate this saw to the point of being impractical.

Cans failing inspections or damaged in the process after the bagless transfer system have to be brought back to the bagless transfer glovebox to repackage the ceramic pucks. This would be a significant challenge for an 80 inch long $85 \mathrm{lb}$. can in a glovebox environment.

\section{Cans per DWPF Canister}

To achieve the required amount of $\mathrm{Pu}$ in each DWPF canister, the can loading units will generate fifty six 10 inch cans, twenty eight 20 inch cans, or seven 80 inch cans. Each puck can has a bottom thickness and a top section occupied by the hollow plug bottom half. This total additional length is approximately 1 inch. Eight nominal 10 inch cans produce a column height of approximately 88 inches, four nominal 20 inch cans produce a column height of approximately 84 inches, and one nominal 80 inch can produces a column height of approximately 81 inches. Additional length for a bottom orientation section at the magazine bottom and at the magazine top for a lifting section and a latching device would be required for all three can heights. This may make the total height of the 20 inch can magazine and particularly the 10 inch can magazine too close to or even above the 91 inch glass level in the DWPF canister. However, the nominal diameter of the ceramic puck could be increased from 2.625 inches to 2.75 inches and still be practical to be loaded into the 2.88 inch inner diameter can. This would reduce the total column height for all three can lengths by 7 inches, to be compatible with the 91 inch glass height and still produce the same volume (and amount) of ceramic and plutonium in each DWPF canister.

\section{Glovebox Design}

A 10 inch can may be accommodated by the current SRS Bagless Transfer frame dimensions, and utilized under most standard glovebox configurations without much difficulty. This is valuable in that the unit is already proven in hot operation, thus reducing development/modification costs. A 20 inch can requires the frame to be redesigned to extend the travel of both the can loader and tool axes. The main difference between the 10 inch and the 20 inch cans is that the 20 inch cans require the glovebox frame to be designed with a greater amount of clearance under the glovebox (to allow the new can to be inserted) and a raised roof to accommodate a full length ejection of a failed can into the glovebox. Since the immobilization facility will be new, a nonstandard design glovebox should be easily accommodated. If an 80 inch can is used, it will be impractical to process in the vertical orientation, thus requiring a glovebox with an 80 inch long access way for 
can entry on one side, as well as an 80 inch long wing on the other side to allow the ejection of a failed can, which would increase the facility footprint. It is possible to use a cutoff saw inside the box in lieu of the ejection wing, but it is felt that the glovebox would have to be made wider to accommodate this saw to the point of being impractical.

An automated system will load new puck cans into the can loading system and remove cut puck cans from the system. This automated puck can handling system must be included in the glovebox design for any length puck can.

\section{Estimated Cycle Time}

The SRS FB-Line Bagless Transfer system has a theoretical cycle time of approximately 1 hour. Procedures necessary in a nuclear environment extend this time to 2 hours. A 2 hour cycle is estimated for all three can lengths. This estimation is based on experience from the operating bagless transfer system at the SRS FB-Line facilities. The 10 inch can requires 56 cycles (welds) per day, the 20 inch can requires 28 cycles per day, and the 80 inch can requires 7 cycles per day.

\section{Can Loading Units}

To determine the number of can loading units, this report assumes each puck is $25 / 8$ inch in diameter and 1 inch thick (nominal dimensions), the can loading cycle time is 2 hours, the facility loads $1 \mathrm{DWPF}$ canister per day, and each canister holds 7 magazines. With these assumptions, five 10 inch can loading units, three 20 inch units, or one 80 inch unit is required. Note, when the 80 inch can loading unit fails, all production will stop so two units may be prudent. The leak check and smear test systems are included in each can loading unit.

\section{Non-Destructive Assay Equipment}

Each of the product cans from the can loading system must be non-destructively assayed. The size of the cans will impact the quantity of accountability instruments required to perform these measurements. For example, using 10 inch cans instead of 20 inch cans will double the calorimeters required if this type instrument is used in the assay analysis system. The 80 inch long cans will of course require the fewest number of instruments, however, the excessive length may cause problems in designing equipment to obtain accurate readings. The equipment to assay an 80 inch can may require a significant development effort due to the long can length. Mixed Oxide fuel facilities pass long fuel rods through a continuous assay system. This assay method may produce acceptable results and thus reduce development time.

\section{Loaded Can Storage}

Storage vaults will be provided in the immobilization plant to store and stage product prior to, during and after the canister loading operations. The storage capacity will be a combination of loaded cans, loaded magazines and loaded canisters. The can length will determine the quantity of storage positions for cans in the storage vault, although multiple cans could be stored in each storage position so that the storage positions and storage area required for each size can would be similar. The loaded magazine and loaded canister capacities will be unaffected by can length.

\section{Waste Generation}

The scrap stub cut from each welded puck can will be disposed of as waste. A 10 inch puck can system generates 56 stubs per day (20,440/year), a 20 inch puck can system generates 28 stubs per day (10,220/year), and an 80 inch puck can system generates 7 stubs per day (2,555/year). Damaged and reject cans add to the waste volume, however, this study does not quantify this 
waste stream. An automated waste handling system will be designed to compact this waste for disposal. With the low potential for contamination, this waste stream is expected to be nontransuranic waste.

\section{Process Operations}

The number of can loading cycles required to fill a DWPF canister is related to can length. The 10 inch can requires 56 cycles, the 20 inch can requires 28 cycles, and the 80 inch can requires 7 cycles to fill a canister. Each can loading cycle requires an NDE equipment cycle, an NDA equipment cycle, and a material handling equipment cycle.

Increasing the ceramic puck diameter from 2.625 inches to 2.75 inches, as previously mentioned, could reduce the number of can loading cycles per DWPF canister. Assuming that the reject rate for the can loading operation is constant regardless of can length, then the fewest number of can loading rejects per DWPF canister would be with the 80 inch can. This must be weighed against the problems of handling an 80 inch long, $85 \mathrm{lb}$. reject can.

\section{Radiation Dose to Personnel}

The can loading system will normally operate automatically. This includes bringing new cans to the system, loading pucks and plugs into cans, removing welded cans and stubs from the system so personnel will not receive any radiation dose. Welding problems will be resolved by ejecting the can into the can loading glovebox. Initial can loading concepts reveal that automating the ejection process may be impractical, requiring operators to process failed cans. Proper shielding can be used where possible, however, there are certain steps of ejecting failed cans that expose personnel to some radiation dose. Radiation from the cans does not increase significantly as length increases, which indicates that with a constant reject rate that reject 10 inch cans would have to be handled twice as often as 20 inch cans, but increased time to handle the heavier 20 inch can would probably mean somewhat less than twice the total exposure in handling rejects. Although the fewest number of can rejects per DWPF canister can be expected for the 80 inch can, the increased time required to handle the long, heavy can with mechanical assistance may significantly or even totally offset the reduction in radiation exposure due to the increased time for the operator to handle each reject.

\section{DEVELOPMENT AREAS}

This report identified the following issues that require further development to ensure a successful $\mathrm{Pu}$ Immobilization can loading system.

- Unload pucks from trays

- Weigh and inspects pucks

- Load pucks and plugs into puck cans

- Deliver puck cans to the can loading system

- Remove cut cans from the can loading system

- Handling and size reduce can stubs

- Can smear test

- Can leak test

- Can integrity during glass pouring operations 


\section{CONCLUSIONS}

This report recommends a puck can with a 3 inch outer diameter and 0.06 inch nominal wall thickness. Can wall thickness requires more analysis to verify hot DWPF glass will not compromise can integrity. The recommended can length is 20 inch nominal and the reasons for this recommendation follow. The 80 inch can is attractive from the standpoint of a reduced number of cans, reduced number of welding operations, reduced number of can loading units, reduced material handling steps, and potential for magazine elimination or at least simplified magazine loading. However, the cost, time, technical risk required to develop the horizontal welding technology, reliability for a horizontal unit, and the problems in remotely handling such a long and heavy can in a glovebox environment eliminates it from further consideration. The advantages for the 10 inch can include lower development costs and greater flexibility in magazine loading design. The 10 inch can presents significant facility concerns in terms of number of can loading units to meet production requirements, supporting accountability systems, waste, storage, the number of operations, number of rejects and radiation exposure in handling rejects. The 20 inch cans require a taller can loading system, however, it will make use of the current design. The 20 inch can represents a reasonable compromise between process efficiency, development costs, capital costs, and technical risk. For these reasons the nominal 20 inch can length is recommended, see Attachment 3. 


\section{Attachment 1 - Bagless Transfer Process}

Step 1 - Insert Can

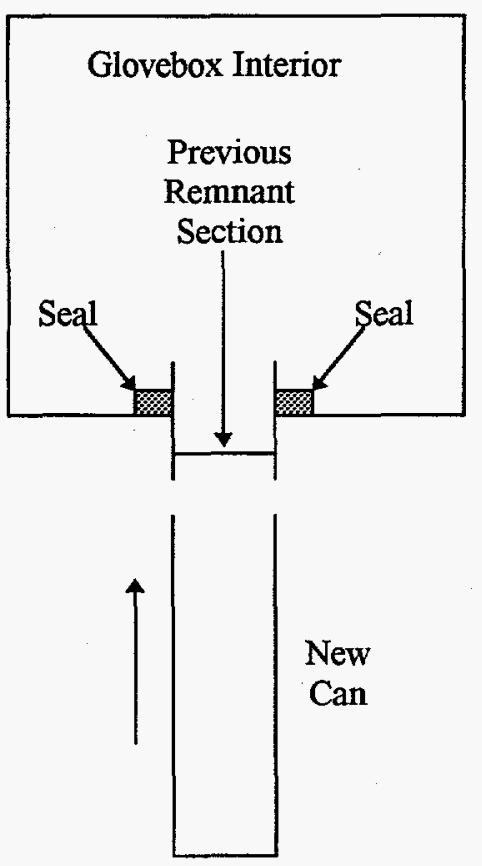

Step 4 - Cut Can

In Middle of Weld

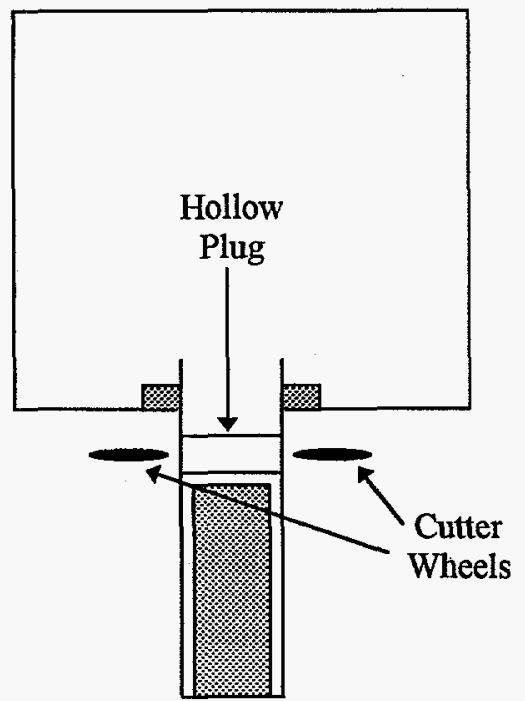

Step 2 - Fill Can

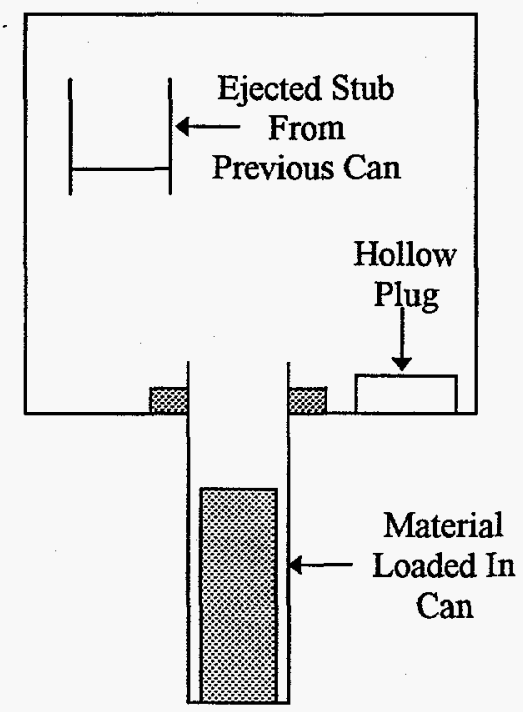

Step 3 - Insert Hollow

Plug and Weld

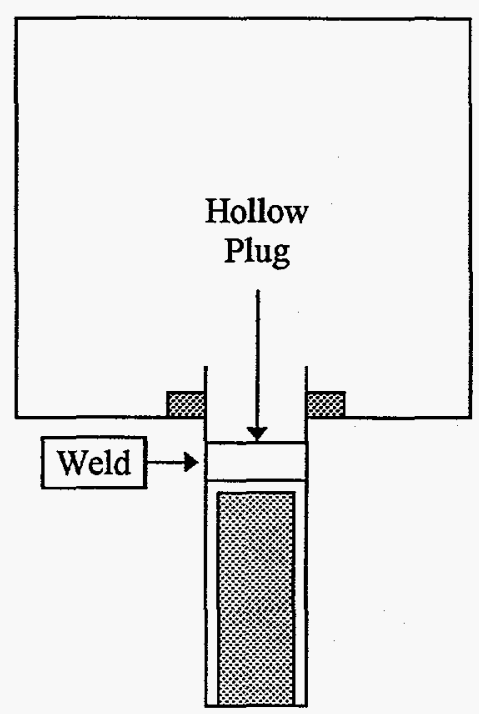

Step 5 - Separate Cans

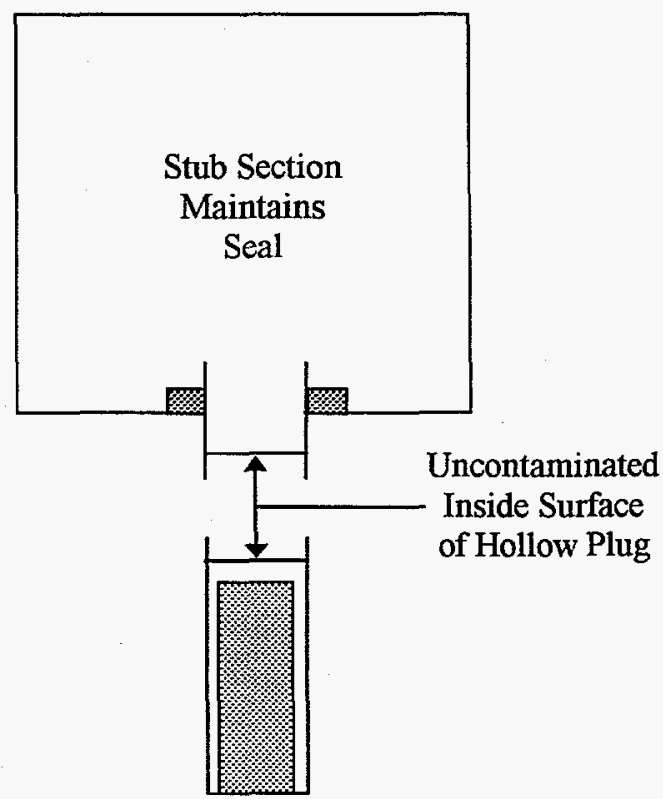




\section{Attachment 2 - Puck Can Evaluation}

\begin{tabular}{|c|c|c|c|c|}
\hline$\#$ & Item & $10 "$ Can & $20 "$ Can * & 80" Can \\
\hline 1 & Can Diameter (inches) & $3^{\prime \prime}$ & $3^{\prime \prime}$ & $3 "$ \\
\hline 2 & Cut Can Length (inches, nominal) & 10 & 20 & 80 \\
\hline 3 & Cans per Magazine & 8 or 7 & 4 & 1 \\
\hline 4 & Can Fabrication & Standard Fab. & Standard Fab. & Potential Problem \\
\hline 5 & Can Wall Thickness & Same & Same & Thicker \\
\hline 6 & Reject and Damaged Can Requirements & Standard & Standard & Add Wing or Saw \\
\hline 7 & Cans per DWPF Canister & 56 & 28 & 7 \\
\hline 8 & Glovebox Frame & Current & Extended & New Design \\
\hline 9 & Clearance Under Glovebox & No & Yes & Unknown \\
\hline 10 & Raised Glovebox Roof & No & Yes & Unknown \\
\hline 11 & Standard Glovebox & Yes & Yes & New Design \\
\hline 12 & Glovebox Orientation & Vertical & Vertical & Horizontal \\
\hline 13 & Estimated Cycle Time (hours) & 2 & 2 & 2 \\
\hline 14 & Can Loading Units & 5 & 3 & 1 \\
\hline 15 & NDA Equipment & $8 X$ & $4 X$ & $\mathrm{X}$ (high risk) \\
\hline 16 & Loaded Can Storage & $8 X$ & $4 \mathrm{X}$ & $\mathrm{X}$ \\
\hline 17 & Waste Generation & $8 X$ & $4 X$ & $\mathrm{X}$ \\
\hline 18 & Process Operations & $8 X$ & $4 \mathrm{X}$ & $\mathrm{X}$ \\
\hline 19 & Radiation Dose to Personnel & $>\mathrm{X}$ & $>X$ & $\mathrm{X}$ \\
\hline
\end{tabular}

* Recommended Can Length 
Attachment 3 - Sketch of Recommended Puck Can
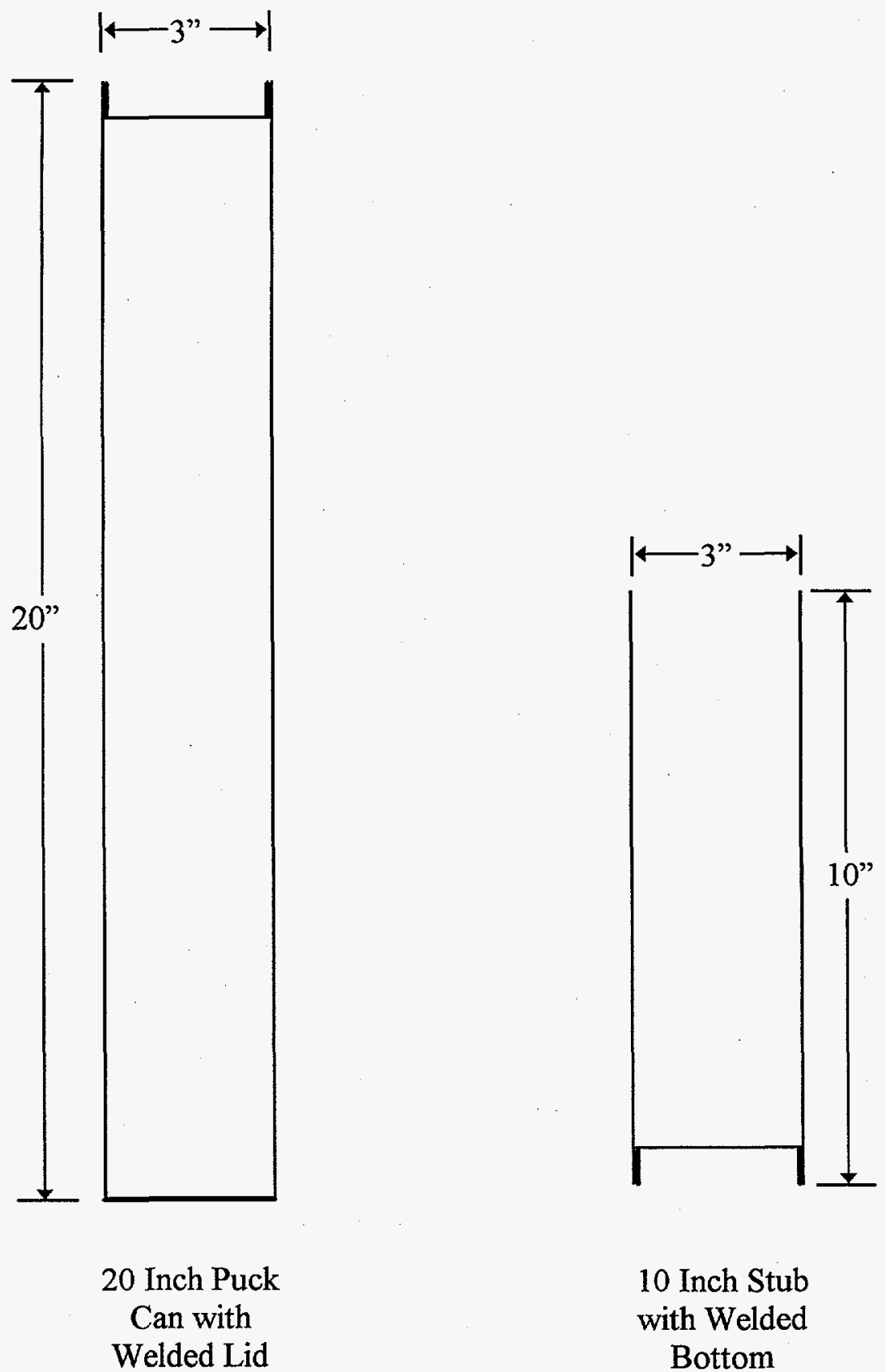

10 Inch Stub with Welded Bottom 